\title{
Indexation, internationalization and professionalization
}

A country that wishes to have competitive, quality science at the international level can not do without good scientific journals. Thanks to the efforts of the scientific community, of the National Council for Scientific and Technological Development (CNPq), of the Brazilian Federal Agency for Support and Evaluation of Graduate Education (CAPES) and, above all, of the international visibility gained by the Scientific Electronic Library Online (SciELO), Brazilian researchers today can take pride in their scientific journals. There is no other reason that, in 2009, 103 Brazilian journals are indexed in the Thomson Reuters ISI data base.

One of the objects most desired by Brazilian scientists always was to have their journals indexed by ISI. Having attained that goal, the next is to increase the international prestige of the Brazilian scientific journals. For this, it should be sufficient if each Brazilian scientist were to submit papers of high quality for publication in the journals of their respective areas.

Who, some years ago, could imagine that articles published in the Journal of the Brazilian Chemical Society (JBCS) would have more than 100 citations or that the journal would attain an index factor ${ }^{1}$ of 1.5 ? Today this is a reality and, thanks to these indices, in 2009 JBCS should receive more than 800 manuscripts, the majority from outside of Brazil. ${ }^{2}$ For this reason, the editors of JBCS have resolved to publish ten issues this year, instead of the eight usually edited in one year. ${ }^{3}$

To increase the periodicity of JBCS is not a simple task for the editors or for those that work in the JBCS office. It also requires, from the chemical community, more agility in emitting reviews of the manuscripts as well as the submission of high quality manuscripts.
On the other hand, this same community ought to require of the Directorate and Council of the Brazilian Chemical Society (SBQ) the professionalization of its scientific publications, since the SBQ is the only Brazilian scientific society that publishes three print journals - JBCS, Química Nova and Química Nova na Escola - and an electronic page, Química Nova Interativa (QNint). ${ }^{4,5}$

Actually, there is much talk in the Brazilian Congress about the distribution of the royalties from the "pre-salt" explorations. If the members of Congress wish to guarantee the entrance of Brazil into the select group of developed nations, effort must be expended so that a considerable part of these resources are destined for Science and Technology and that $\mathrm{CNPq}$ has more resources to finance the professionalization of Brazilian scientific journals.

Indexation, internationalization and professionalization are an indissociable triad. To professionalize the Journal of the Brazilian Chemical Society and the other publications of the SBQ is a goal of the SBQ Directorate and Council and of the editors of its journals.

Angelo C. Pinto (UFRJ) JBCS Editor

\section{References}

1. Pinto, A. C.; de Andrade, J. B.; Quim. Nova 1999, 22, 448.

2. Pinto, A. C.; Cunha, A. S.; Quim. Nova 2008, 31, 2221.

3. Torresi, S. I. C.; Pardini, V. L.; Dias, L. C.; Pinto, A. C.; de Andrade, J. B.; Magalhães, M. E. A.; de Almeida Gil, P. E.; Quim. Nova 2007, 30, 1491.

4. de Andrade, J. B.; J. Braz. Chem. Soc. 2009, 20(4), v.

5. http://qnint.sbq.org.br/qni/, acessed in September, 2009. 